 \\ UF | \\ IFAS Extension
}

\section{Keeping it Safe: Extension Cords ${ }^{1}$}

Mary N. Harrison ${ }^{2}$

Use extension cords only when necessary. It is best to plug an electrical device directly into the wall outlet if you can. That is not always possible. Outlets often are not in the locations where they are needed. To resolve this problem you will need an extension cord-you will also need the correct type of cord. Using the wrong kind of cord, or using it incorrectly can create safety hazards such as fire, shock, electrocution, trips and falls, and blown fuses.

\section{Shopping For an Extension Cord}

Almost all extension cords are labeled with much information. This information will help you to choose the correct cord for the intended use.

Read the label and instructions carefully to know which extension cord fit your needs. Look for:

- Total watts the cord will carry.

- Volts of current the cord will carry. Most electrical uses require 110-120 volts. Some heavy-duty equipment such as an electric stove or clothes dryer, require 220 volts. You cannot use a 120 -volt cord or equipment on a 220 line. It will burn out the cord and equipment.
- Gauge of wire: The size of wire indicates the amount of electrical current-watts- that can be safely carried by the wire.

- Also look for the UL Seal of Approval, which means the extension cord meets certain safety standards.

Table 1 shows the relationship of wire size (gauge) to the amount of current that it will safely carry.

Other Considerations:

- If the plug has two prongs it is intended to fit into an outlet of the same pattern.

- Does the cord accept grounded plugs, that is plugs with three prongs? (In case you decide to use an extension cord that has only two openings for prongs with an appliance that has a three-prong plug, NEVER remove the third prong. Purchase an adapter to use with the cord and appliance).

- Some inexpensive, lightweight cords have very shallow receptacles so the plug-in will not fit snugly. If a gap is left this could create a safety problem.

1. This document is FCS5233-03, one of a series of the Department of Family, Youth and Community Sciences, Florida Cooperative Extension Service, Institute of Food and Agriculture Sciences, University of Florida. Publication: May 2002. Revised: December 2005. Please visit the EDIS Web site at http://edis.ifas.ufl.edu.

2. Mary N. Harrison, professor, Department of Family, Youth and Community Sciences, Cooperative Extension Service, Institute of Food and Agricultural Sciences, University of Florida, Gainesville, 32611.

The Institute of Food and Agricultural Sciences (IFAS) is an Equal Opportunity Institution authorized to provide research, educational information and other services only to individuals and institutions that function with non-discrimination with respect to race, creed, color, religion, age, disability, sex, sexual orientation, marital status, national origin, political opinions or affiliations. U.S. Department of Agriculture, Cooperative Extension Service, University of Florida, IFAS, Florida A. \& M. University Cooperative Extension Program, and Boards of County Commissioners Cooperating. Larry Arrington, Dean 
- Where is the cord to be used, indoors or

out-of-doors? Out-of-doors must be much better

insulated against moisture and the elements.

NEVER use indoor cords out-of-doors.

Table 1.

\begin{tabular}{||l|l|l|l|l||}
\hline \hline Cord Type & Guage & Amps & Total Amps & Volts \\
\hline $\begin{array}{l}\text { Lightweight cord (lamp, } \\
\text { radio) }\end{array}$ & 18 gauge & 7 AMPS & 875 total watts & 125 volts \\
\hline $\begin{array}{l}\text { Medium use cord } \\
\text { (small electrical } \\
\text { equipment) }\end{array}$ & 16 gauge & 13 AMPS & 1625 total watts & 125 volts \\
\hline $\begin{array}{l}\text { Heavy duty cord } \\
\text { (computer, printer, } \\
\text { refrigerator) }\end{array}$ & 14 gauge & 15 AMPS & 1825 total watts & $\begin{array}{l}125 \\
\text { volts }\end{array}$ \\
\hline $\begin{array}{l}\text { Heavy duty cord (air } \\
\text { conditioner, clothes } \\
\text { dryer, range top, oven) }\end{array}$ & 12 gauge & 20 AMPS & 5000 watts & $\begin{array}{l}220 \\
\text { volts }\end{array}$ \\
\hline
\end{tabular}

\section{Safety Concerns}

- Never run or place an extension cord under a

rug. Under a rug the extension cord can cause a

fire under certain conditions.

- Before using an old cord inspect it carefully for broken places or worn insulation. Old extension cords have caused many fires and given many shocks.

- NEVER remove a cord from the outlet by pulling on the cord. 